THURSDAY, JANUARY 18,1872

\section{THE SOLAR ECLIPSE}

SURELY if eclipse expeditions had their mottoes, that of the expedition of this year should be per mare per terram; for it has been per mare per terram in our case with a vengeance! Probably when we return, the curious individuals who total up in the Times the aggregate number of years those people have lived whose deaths are there recorded, will, in asking us for our autographs, beg also a detailed statement of the number of miles each of us has travelled in the performance of our duty. I fear it will be very difficult to give the information; and if the temperature in the shade be wanted too, the thing will be perfectly hopeless; for, thank goodness, we took the precaution to bring no thermometers; had we done so and looked at them, it might have been all over with us. Let me point my remarks. A week ago I was at Bekul, having travelled I know not how many thousand miles by sea, and having scarcely set foot on land for a month. We were in the jungle, the heat was burning, some of us had fever, and it was opium which enabled me at all events to get through the eclipse, for it was that memorable day just a week ago. Since then, by night and by day, Dr. Thomson, Captain Maclear, and myself, have beenI seek a word, wafted is too weak, jolted is too strong, for some parts of our journey, though ridiculously lacking in expression for others - well, conveyed from Bekul, now in men-carried conveyances, the cunning bearers with their plaintive moaning, by no means unmelodious, keeping step, giving us an idea of the tremendous labour they were undergoing, and reminding us of a certain journey which we must all make once; now on men's shoulders, now in bullock bandy, speed about two miles an hour, thanks to a brutal breach of contract, which has upset my plans terribly, now in Indian railway carriages, average speed ten miles an hour, temperature of carriage at noon unknown, and lastly in the horse transit of the Madras Carrying Company. Oh! that their carriages were as good as their arrangements and the speed of their horses; and, now, here I am shivering, surrounded by hoar frost, with a soupçon of a difficulty of breathing in this higher air after the dense atmosphere of the jungles, but all the same in an earthly paradise with hedges of roses although it is mid-winter, the whole place a perfect garden. I am at Ootacamund, at an elevation of some 7,000 feet with an Australian fauna; and within a few hours I hope to see Janssen, who is still here; Tennant, Herschel, and Hennessy I have unfortunately missed, owing to the breach of contract already referred to.

We can all of us, or nearly all of us, afford to laugh now at any inconveniences we have suffered; for of the eleven who landed at Galle nine have seen the eclipse, some of us perhaps as an eclipse has never been seen before. Unfortunately, to the regret of all, Mr. Abbay and Mr. Friswell, who were among the best prepared for doing good work, and were at a station at which everybody said cloudless weather was certain, found themselves on the I th in a storm of cloud and mist, which obscured the sun for, I believe, the whole day. With this exception voL. v. the telegrams from all the English parties have been sent regularly, while we have all been thankful to learn from the telegrams which Dr. Janssen and Colonel Tennant have had the great courtesy to send me, that they too saw the eclipse well, as also did Mr. Pogson, as I gather from the newspapers, but of course the details of their observations are still unknown to me. Hence, I can only give the facts observed by the party at Bekul and Poodocottah; Prof. Respighi, who observed at that station, having joined me at Pothanore, the station on the Madras Railway, at the foot of the hills which we ascended yesterday from 4.30 A.M. till I P.M.

But before I say a word about the observations themselves, it is incumbent upon me to express our deep obligations to the supreme Madras and Ceylon Governments for the magnificent manner in which they have aided us. Nothing could be more complete than the arrangements at Bekul made by the collector, $\mathrm{Mr}$. Webster, and his assistant, Mr. McIvor, both for the work to be done and the comfort of those who had to do it. The same must be said for the Poodocottah party, where not only the collector, Mr. Whiteside, but the Rajah did everything in their power, the latter loading the observers with presents when they left. We have at present heard only of the discomforts of the Manantoddy party, and it is clear that here the local arrangements were in strong contrast to those elsewhere. The Ceylon parties, who parted from the main body at Galle, have doubtless been well looked after; as Captain. Fyers, the Surveyor-General of the island, accompanied and aided them in their observations.

This brings us to another part of the arrangements. The Ceylon party had the unreserved use of the Government steamer the Serendib, to take them from Galle to their places of observation, Jaffna and Trincomalee, both on the coast, and the accommodation on board was perfect. The Indian parties proceeded to their various destinations, or the ports on the coast nearest to them, in the Admiral's flag-ship the Glasgow, which, however, could not remain to bring them back, a circumstance which has given rise to very considerable inconvenience and great risk for the instruments, which are now scattered all along the line, to be sent to the coast and from the coast to Bombay or Galle, as circumstances may determine. This of course was not to be helped, and we must hope for the best, especially as all the parties have done their utmost in superintending their repacking, and handing them over in perfect condition to the different Government officers who accompanied each party. Still, although it was not to be avoided, the withdrawal of the ship has been the unfortunate circumstance in the arrangements. Nothing could exceed the kindness of the Admiral, who vacated his own quarters to give us room, of Captain Jones, who took the warmest interest in our proceedings, and helped the arrangements greatly, and by the officers of the ship generally. Without the equal kindness of Mr. Webster at Bekul, the step from the Admiral's cabin into the jungle hut would have been a sevenleague one.

As the mail, the first available one after the eclipse, leaves this place to-day, I must lose no more time in recording preliminaries. I will therefore at once state the general arrangements of the parties, and what $I$ at 
present know of the observations. The stations and observers as finally arranged were as follows :-

Bekul-Analysing Spectroscope, Capt. Maclear and Mr. Pringle.

Polariscope, Dr. Thomson.

Photography, Mr. Davis,

Manantoddy-Analysing Spectroscope, Mr. Friswell. Integrating Spectroscope, Mr. Abbay.

Poodocottah-Spectroscope, Professor Respighi. Sketches of Corona, Mr. Holiday.

Jaffna-Integrating Spectroscope, Capt. Fyers and Mr. Ferguson.

Polariscope, Capt. Tupman and Mr. Lewis.

Photography, Captain Hogg.

Trincomalee-Spectroscope, Mr. Moseley.

Besides these observers, we had at Bekul the valuable assistance of General Selby, commanding the troops in Canara and Malabar (for whose help in supplying guards' tents, \&c., the friends of Science cannot be too thankful), Colonel Farewell, Judge Walhouse, and others, in sketching the Corona. At all stations, of course, most precious help in various ways was given by all present who volunteered for the various duties, though some of them lost a sight of the eclipse in consequence. Among those who helped in this way at Bekul were Mr. McIvor, Mr. Pringle, Captain Bailey who timed the eclipse, Mr. Cherry, and Captain Christie, the Inspector of Police, whose presence there turned out to be of the most serious value, for the natives seeing in the eclipse the great Monster Rahoo devouring one of their most sacred divinities, not only howled and moaned in the most tremendous manner, but set fre to the grass between our telescopes and the sun to propitiate the representative of the infernal gods. Captain Christie with his posse of police stopped this sacrifice at the right moment, and no harm was done.

Now for the observations. Perhaps I may be permitted to begin with my own, as at the present moment I know most about them. I determined to limit my spectroscopic observations to the spectrum of a streamer, and to Young's stratum, thereby liberating a number of seconds which would enable me to determine the structure of the undoubted corona with a large refractor, to observe the whole phenomena with the naked eye, and through a train of prisms with neither telescope nor collimator, and finally with a Savart and biquartz. I found the 120 seconds gave me ample time for all this, but owing to a defect in the counterpoising of my large reflector, which disturbed the rate of my ciock, I missed the observation of the bright line stratum (assuming its existence) at the first contact. At the last contact Mr. Pringle watched for it and saw no lines.

Having missed this, I next took my look at the corona. It was as beautiful as it is possible to imagine anything to be. Strangely weird and unearthly did it look-that strange sign in the heavens! What impressed me most about it, in my momentary glance, was its serenity. I don't know why I should have got such an idea, but get it I did. There was nothing awful about it, or the landscape generally, for the air was dry and there was not a cloud. Hence there were no ghastly effects, due generally to the monochromatic lights which chase each other over the gloomy earth, no yellow clouds, no seas of blood-the great Indian Ocean almost bathed our feet-no death- shadow cast on the faces of men. The whole eclipse was centred in the corona, and there it was, of the purest silvery whiteness. I did not want to see the prominences then, and I did not see them. I saw nothing but the star-like decoration, with its rays arranged almost symmetrically, three above and three below two dark spaces or rifts at the extremities of a horizontal diameter. The rays were built up of innumerable bright lines of different lengths, with more or less dark spaces between. Near the sun this structure was lost in the brightness of the central ring.

But from this exquisite sight I was compelled to tear myself after a second's gazing. I next tried the spectrum of a streamer above the point at which the sun had dis. appeared. I got a vivid hydrogen spectrum, with 1474 (I assume the point of this line from observation) slightly extended beyond it, but very faint throughout its length compared with what I had anticipated, and thickening downwards, like F. I was, however, astonished at the vividness of the $C$ line, and of the continuous spectrum, for there was no prominence on the slit. I was above their habitat. The spectrum was undoubtedly the spectrum of glowing gas.

I next went to the polariscope, for which instrument I had got Mr. Becker to make me a very time-saving contrivance-a double eye-piece to a small telescope, one containing a Savart and the other a biquartz. In the Savart I saw lines vertical over everything-corona prominences, dark moon, and unoccupied sky. There was no mistake whatever about this observation, for I swept. three times across and was astonished at their unbrokenness. I next tried the biquartz. In this I saw wedges, faintly coloured here and there; a yellowish one here, a brownish one there, with one of green on each side the junction, are all the colours I recollect. Then to the new attack-the simple train of prisms which, the readers of NATURE know, Professor Young had thought of as well as myself ; its principle being that, in the case of particular rays given out by such a thing as the chromosphere, or the sodium vapour of a candle, we shall get images of the thing itself painted in that part of the spectrum which the ray inhabits, so to speak, we shall see an image for each ray, as if the prisms were not there. What I saw was four exquisite rings, with projections where the prominences were. In brightness, $C$ came first, then $F$, then $G$, and last of all 14.74 ! Further, the rings were nearly all the same thickness, certainly not more than $2^{\prime}$ bigh, and they were all enveloped in a line of impure continuous spectrum.

I then returned to the finder of my telescope, a $33_{4}^{3}$ inch, and studied the structure of the corona and prominences. One of the five prominences was admirably placed in the middle of the field, and I inspected it well. I was not only charmed with what I saw, but delighted to find that the open-slit method is quite competent to show us prominences well without any eclipse. I felt as if I knew the thing before me well, had hundreds of times seen its exact equivalent as well in London, and went on to the structure of the corona. Scarcely had I done so, however, when the signal was given at which it had been arranged that I was to do this in the 6-inch Greenwich refractor. In this instrument, to which I rushed, for Captain Bailey had. just told us that we had "still 30 seconds more"-which I 
heard mentally, though not with my ears, as "only 30 seconds more"-the structure of the corona was simply exquisite and strongly developed. I at once exclaimed, "like Orion!" Thousands of interlacing filaments varying in intensity were visible, in fact $I$ saw an extension of the prominence-structure in cooler material. This died out somewhat suddenly some $5^{\prime}$ or $6^{\prime}$ from the sun, I could not determine the height precisely, and then there was nothing; the rays so definite to the eye had, I supposed, been drawn into nothingness by the power of the telescope; but the great fact was this, that close to the sun, and even for $5^{\prime}$ or $6^{\prime}$ away from the sun, there was nothing like a ray, or any trace of any radial structure whatever to be seen. While these observations were going on, the eclipse terminated for the others, but not for me. For nearly three minutes did the coronal structure impress itself on my retina, until at last it faded away in the rapidly increasing sunlight. I then returned to the Savart, and saw exactly what I had seen during the eclipse, the vertical lines were still visible!

Captain Maclear has promised to forward to you himself an account of his observations. I need only here therefore refer to their extreme value, adding what I should have stated before, that I saw the bright lines at the cusps; as he was so good as to draw my attention to them. I am however not prepared to say that they were visible through a large arc of retreating cusp.

Dr. Thomson confined his observations to the polariscope, using the Savart. He states that his observations were identical with my own.

Mr. Davis's photographic tent was below the cavalier in which our telescopes had been erected; and immediately after the observations I have recorded were over, I went down to see what success had attended his efforts. I was hailed when half-way there with the cheering intelligence "five fine photographs," and so they are, those taken at the beginning and end of the eclipse being wonderfully similar, with, I fancy, slight changes here and there; but on this point I speak with all reserve until they have been examined more carefully than the time at our disposal has permitted, and until they have been compared with those taken at Ootacamund, Avenashi, and, I hope, at Jaffna and Cape Sidmouth.

This exhausts the principal work done by the BekuI party, with the exception of the sketchers with General Selby at their head, who have recorded most marked changes in the form of the outer corona, and Mr. Webster, who was so good as to photograph the eclipse from a fort some eight miles away, with an ordinary camera, and obtained capital results.

Next a word about the Poodocottah, the other fortunate Indian party. Prof. Respighi has promised to send his results to you with this. About Mr. Holiday's labours i know nothing, except that he has obtained three sketches.

Concerning the Ceylon parties I give you a verbatim extract from the telegrams. From Jaffna: "Exceedingly strong radial polarisation, $35^{\prime}$ above the prominences; corona undoubtedly solar to that height, and very probably to height of $50^{\prime}$." From Trincomalee Mr. Moseley informs me that he carefully watched for Young's bright line stratum, and did not see it, and that I 474 was observed higher than the other line.

This is the sum total of the information which has at present reached me. It is clear there are discordances as well as agreements, the former being undoubtedly as valuable as the latter. It remains now to obtain particulars of all the observations of all the parties, before a final account can be rendered of the eclipsed sun of $187 \mathrm{I}$. This, of course, will be a work of months; but if all goes well, I trust to obtain information shortly of the outlines of the work done by the Indian observers and M. Janssen, as I am now remaining in India for that purpose, and this I will communicate to NATURE by the earliest opportunity. In the meantime I hope the good people at home will think we have done our duty, and that all the members of the Government Eclipse Expedition of 1871 will soon be safely with them to give an account of their work.

Ootacamund, Dec. 19, 1871

\section{J. NORMAN LOCKYER}

\section{CAPTAIN MACLEAR'S OBSERVATIONS}

I ONG before this, no doubt, you have heard of the 1 success of the expedition, but you must be anxious to hear more of the details, and what the observations really were. When I last wrote to you from Point de Galle," the expedition had arrived there on November 27 th in the Mirzapore, and was about to proceed to the different stations selected. The Ceylon sections left on the 28 th in the Colonial steamer Serendib, placed at our disposal by the Government. She was to leave Messis. Moseley and Ferguson at Trincomalee, and then proceed to Jaffna, with Captain Fyers, R.E., Captain Tupman, R.M.A. and Mr. Moseley. We have since heard of the safe arrival of these gentlemen at their stations, and, by telegraph, of their successful observations on December I 2 th.

The Indian parties left Galle on the 28th in H.M.S. Glasgow, flag-ship of Admiral Cockburn, who kindly gave us his cabin accommodation. With a fair wind we made sail, and arrived at Beypore on the night of the Ist December. The next morning we landed Signor Respighi and Mr. Holiday to go by train to Poodocottah, and then we left for Cannanore where Messrs. Abbay and Friswell were disembarked to make their way across country to their station at Manantoddy. They had a troublesome and fatiguing journey to perform, with heavy instruments, which however they safely accomplished in three days, and we can only heartily regret that their labours were not recompensed by fine weather on the morning of the eclipse. At Cannanore we were fortunate enough to enlist the services of General Selby, commanding the troops; he came across to Bekul, and rendered good aid in making some valuable sketches of the corona during the eclipse.

We left Cannanore on the $3 \mathrm{rd}$, and with the strong tide that sometimes runs up that coast, were only six hours in reaching Bekul. We found that $\mathrm{Mr}$. McIvor, assistant collector, and Mr. Pringle, engineer, had arrived that morning from Mangalore, on the part of the Indian Government, had prepared the travellers' bungalow for our reception, and had cleared the keep of an old fort erected by Tippoo which would make a capital observatory. The bay is open and shelving, but there

* See Nature, vol, v. p. $x 63$. 